International Journal of Business Economics (IJBE)

Vol, 2 Issue 2, pp 76-85, March - August 2021

http:/ /jurnal.umsu.ac.id/index.php/ijbe

eISSN 2686-472X

ORIGINAL ARTICLE

\title{
Technopreneurs Millennial in Indonesia: The Acquisition and Application Knowledge
}

\section{Ardianus Laurens Paulus}

\begin{abstract}
The development of technical knowledge has encouraged many business activities utilizing communication tools and technologies in business processes. This study aims to test the effect of knowledge acquisition and knowledge application of millennial technopreneurs in Indonesia in utilizing technology for their business activities. A total of 153 respondents were surveyed through online questionnaires. SEM analysis is used to test the research model. This study found that millennial technopreneurs ignore acquiring knowledge about business activities. But significant results showed that millennial technopreneurs immediately applied knowledge without looking at previous knowledge acquisition processes.
\end{abstract}

Keywords:Knowledge Acquisition, Knowledge Application, Technopreneur, Millennial

DOI :https://doi.org/10.30596/ijbe.v2i2.5052

JEL Classification : O, M3, L26

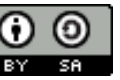

Published by International Journal of Business Economics (IJBE), Indonesia | Copyright (C) 2021 by the Author(s) | This is an open access article distributed under the Creative Commons Attribution License http://creativecommons.org/licenses/by/4.0), which permitsunrestricted use, distribution, and reproduction in any medium, provided the original work is properly cited.

Cite this article as:

Paulus, A. L, (2021). Technopreneurs Millennial in Indonesia: The Acquisition and Application Knowledge. International Journal of Business Economics (IJBE), 1(1), 76-85.

Departement of Management, Faculty of Business

Universitas Katolik Widya Mandala Surabaya Kampus Madiun

Jalan Manggis No. 15-17, Madiun, Jawa Timur.

*Corresponding Author: ardianus@staff.widyamandala.ac.id 


\section{International Journal of Business Economics (IJBE)}

Vol, 2 Issue 2, pp 76-85, March - August 2021

http:/ /jurnal.umsu.ac.id/index.php/ijbe

eISSN 2686-472X

\section{INTRODUCTION}

The development of technology-based business is growing and developing, with the emergence of various start-up businesses increasingly popular in Indonesia (Jakartapost.com, 2017). Technology-based entrepreneurs have emerged in developing countries such as Indonesia because many products from the global market have entered the country. Research from The Economist Intelligence Unit (2017) predicts that some traditional business models will experience tension due to changes that are driven by technology. Besides, Ngah and Ibrahim (2009) found that there were significant differences in individual abilities causing the use of technology to be widespread in Asian countries such as Indonesia compared to western countries. It is important to realize by millennial entrepreneurs from developing countries such as Indonesia to compete in advanced information and communication technology today by mastering business knowledge. By relying on technology in business processes, the term known as technopreneur is a modern entrepreneur who uses technology in running his business. Technopreneur has emerged in Indonesia in recent years and has great potential to continue to grow in the future (Dailysocial.id, 2016). Besides the increasing number of millennial young entrepreneurs or new businesses in the technology and creative industries.

According to W\&S Market Research (2014), the Indonesian e-commerce market has the opportunity to continue to grow, considering that internet and smartphone users are increasing in Indonesia. Millennials or Generation Y (born in the 1980s-2000s) are groups of people born after Generation X. Millennial generation is special because it is very different from previous generations related to technology (Livescience.com, 2017). Research from ManpowerGroup (2016) in 25 countries found that the millennial generation's careers have changed and left the old ways of working. Most millennials are digital entrepreneurs and innovators in their respective fields. Among the 255 million registered population in Indonesia, 81 million are a millennial generation or aged 17 - 37 years. It means that Indonesia has many opportunities through the millennials' generation to develop their country, which is entrepreneurship, by utilizing information technology that is currently developing (Idntimes.com, 2017). Thus, millennial generation entrepreneurs need to adapt to advances in information technology by acquiring existing knowledge that finds, select, organize, and present information on their respective businesses are engaged in a certain way. It will increase the mastery of knowledge related to customers, products, and competitors and suppliers. The knowledge embedded within the millennial entrepreneur needs to be applied so that the knowledge can be used and applied optimally in business activities. Applying knowledge needs to be improved by acquiring knowledge from external parties and then internalizing that knowledge in the occupied areas (Darr and Epple, 1995). The process of knowledge acquisition and knowledge application must be applied intensively to develop over time to achieve a sustainable competitive advantage (Nonaka and Takeuchi, 1995).

Research Hwa (2009), in automotive companies in Singapore, found that technopreneur is influenced by the knowledge that individuals personally own. The knowledge gained from other people through the process and stages is then formulated into a strategy of using the tools/devices that assist in implementing such knowledge. Then, Mohannak and Matthews's (2011) research on SME companies in Australia found that knowledge management processes that consist of knowledge acquisition impact the use of technology to produce innovation so that knowledge integration can occur in business routinely and support company management. Bon's research (2010), that young technopreneur in Malaysia 


\section{International Journal of Business Economics (IJBE)}

Vol, 2 Issue 2, pp 76-85, March - August 2021

http:/ /jurnal.umsu.ac.id/index.php/ijbe

eISSN 2686-472X

obtained information and knowledge about technology-based entrepreneurship, started from universities' training. Smith (2003) examined the technopreneur in Asia, especially in Singapore, found that entrepreneurs' success is driven by technology and the role of leaders in applying their knowledge to apply knowledge skills by building new systems and processes, exploiting special knowledge, and building the strong brand image. Pratomo (2010) explains technopreneur needs to manage knowledge. Knowledge management needs to be abandoned traditionally and needs to accommodate changes in complex situations quickly. In fast-paced and complex conditions, technopreneurs need to have a decision support system to help carry out strategic tasks.Knowledge management systems play an important role in acquiring knowledge while helping to develop technopreneurs. Business processes in the current era encourage millennials to tend to use technology in carrying out business activities. The knowledge that has been obtained from various sources can be applied to business activities to support success. Research Madhousi et al. (2011) conducted on technopreneur in Iran gives the results that knowledge management is very dependent on effective management and utilization of knowledge in practice used. According to Mohannak and Matthews (2011), the utilization and application of knowledge management by technopreneur is very dependent on the tools used by company management. It is related to research and development in the process of technology-based business orientation. The findings provide the results that knowledge management, which consists of the knowledge application, needs to be applied formally and needs to be embedded in routine organizational activities. In the research of Mehdi and Shaemi (2010), automotive companies in Iran gave the results that in applying knowledge, companies need to pay attention to creating, establishing, and disseminating knowledge into company management through data and then processing it into useful information for the organization. Then Pratomo (2010) also explained that knowledge management systems play an important role in applying knowledge agents (millennials). A knowledge management system will greatly assist the development of millennial technopreneur in a better direction.

This study examines the effect of knowledge acquisition and knowledge application on the use of technology for millennial entrepreneurs in Indonesia. Developments in information technology drive many business activities or business utilizing communication tools and technologies in business processes. Millennial entrepreneurs can seek knowledge about the business model that is done by gaining knowledge from many available sources through technology that can be utilized.

\section{METHOD}

A quantitative approach used in this study through a survey method to test young entrepreneurs' perceptions (millennial), which uses technology in business processes. The data analysis technique is SEM (Amos 21), and the estimation technique is Maximum Likelihood Estimation (MLE). The sample's determination is nonprobability sampling with purposive and snowball sampling techniques (Cooper and Schindler, 2011). Primary data is self-report through a self-administered survey with an online survey using Google form. This study tested the validity and reliability of the constructs first. The research instrument on knowledge acquisition and knowledge application was adopted from Gold et al. (2001), while the technopreneur instrument was adopted from Howe and Straus (2007). The validity test was carried out using face validity, convergent validity, and discriminant validity, while the reliability test was using construct reliability - cr (Hair et al., 2010). The sample adequacy has met the assumptions recommended by Hair et al. (2010), which is 153 number of samples. 


\section{International Journal of Business Economics (IJBE)}

Vol, 2 Issue 2, pp 76-85, March - August 2021

http://jurnal.umsu.ac.id/index.php/ijbe

eISSN 2686-472X

Evaluation of outliers based on the degree of freedom a variable number of indicators at the level of significance (Mahalonabis Distance). No Mahalanobis Distance cases were found so that the whole observation can be used in the next step of testing (Hair et al., 2010).

Table 1. Test of validity and reliability (Standardized Factor Loading, Average Variance Extracted and construct reliability)

\begin{tabular}{|c|c|c|c|c|c|}
\hline Construct & Item & Standardized Factor Loading & AVE & CR Value & Description \\
\hline Knowledge & X3 & 0.737 & 0.500 & 0.850 & Valid \& Reliable \\
\hline \multirow[t]{5}{*}{ Aquisition } & $\mathrm{X} 4$ & 0.695 & & & \\
\hline & $\mathrm{X} 5$ & 0.641 & & & \\
\hline & X6 & 0.786 & & & \\
\hline & $\mathrm{X} 7$ & 0.701 & & & \\
\hline & $\mathrm{X} 8$ & 0.653 & & & \\
\hline Knowledge & $\mathrm{X} 10$ & 0.751 & 0.550 & 0.918 & Valid \& Reliable \\
\hline \multirow[t]{9}{*}{ Application } & X11 & 0.751 & & & \\
\hline & $\mathrm{X} 12$ & 0.766 & & & \\
\hline & $\mathrm{X} 13$ & 0.787 & & & \\
\hline & X14 & 0.787 & & & \\
\hline & $\mathrm{X} 15$ & 0.759 & & & \\
\hline & $\mathrm{X} 16$ & 0.670 & & & \\
\hline & $\mathrm{X} 17$ & 0.770 & & & \\
\hline & $\mathrm{X} 18$ & 0.680 & & & \\
\hline & X19 & 0.680 & & & \\
\hline Technopreneur & $\mathrm{Y} 2$ & 0.739 & 0.535 & 0.935 & Valid \& Reliable \\
\hline \multirow[t]{12}{*}{ Millennial } & Y3 & 0.719 & & & \\
\hline & Y4 & 0.804 & & & \\
\hline & Y5 & 0.827 & & & \\
\hline & Y6 & 0.701 & & & \\
\hline & Y7 & 0.726 & & & \\
\hline & Y8 & 0.752 & & & \\
\hline & Y9 & 0.698 & & & \\
\hline & Y10 & 0.684 & & & \\
\hline & Y11 & 0.747 & & & \\
\hline & Y12 & 0.662 & & & \\
\hline & Y13 & 0.679 & & & \\
\hline & Y14 & 0.751 & & & \\
\hline
\end{tabular}

This study analyzes the measurement model using confirmatory factor analysis (CFA). All estimated values for the relationship between indicators and their constructs are significant at the 0.1 level (X1, X2, X9, Y1 are invalid). The standardized factor loading value indicates this, average variance extracted, and a critical ratio above 0.5. Thus all indicators listed in the table are valid and reliable. Based on table 2, the Chi-Square value $\left(\chi^{2}\right)$ is 694,244 . The smaller the Chi-Square value $(\chi 2)$, the more it fits the model with empirical data measurements. Normed Chi-Square ( $\left.\chi^{2} / \mathrm{df}\right)$ is 1.8876 and good because it is smaller than 3.00 (Hair et al., 2010). The measurement model fit with empirical data. In table 2, the GFI model index is 0.773. According to Hair et al. (2010), GFI is better if it is close to a value of 1 (one) or above 0.9 . The results obtained can be said to be a moderate value (above 0.5), and based on this value, it can be concluded that the overall model has a moderate level of conformity. In testing, the model's suitability is evaluated through various criteria for the goodness of fit (GOF). 


\section{International Journal of Business Economics (IJBE)}

Vol, 2 Issue 2, pp 76-85, March - August 2021

http://jurnal.umsu.ac.id/index.php/ijbe

eISSN 2686-472X

Table 2. Assumptions of Goodness of Fit

\begin{tabular}{llll}
\hline Indeks Goodness of Fit & Cut of Value & Model & Description \\
\hline Absolute fit measure & & & \\
Chi Square $\left(\mathrm{X}^{2}\right)$ & Small & 694.244 & Moderate \\
Normed Chi Square (CMIN/DF) & $<3.00$ & 1.876 & Good \\
Probability (P-Value) & $>0.05$ & 0.000 & Less \\
Root Mean Square Error of Approximition (RMSEA) & $<0.08$ & 0.076 & Good \\
Goodness of Fit Index (GFI) & $>0.90$ & 0.773 & Moderate \\
Incremental fit measure & & & \\
Adjusted Goodness of Fit Index (AGFI) & $>0.90$ & 0.733 & Moderate \\
Parsimonious fit measure & & & \\
Parsimonious Goodness of Fit Index (PGFI) & $>0.90$ & 0.658 & Moderate \\
\hline
\end{tabular}

Similar the GFI value, the closer to 1, the AGFI value is considered to be better, and the recommended AGFI value is greater or equal to 0.90 (Hair et al., 2010). This study produces an AGFI value of 0.733 and indicates a moderate level of model suitability. RMSEA value is one index of the size of badness-of-fit. RMSEA value indicates how well the fitness model is estimated in a population, not only in the samples used for estimation (Hair et al., 2010). The smaller the RMSEA value, the better the suitability level, and the RMSEA acceptance value ranges from 0.03 to 0.08 (Hair et al., 2010). The resulting RMSEA value of 0.076 , and this value reflects a good level of model suitability.

\section{RESULTS}

This study was dominated by 120 female millennial entrepreneurs (78.4\%) and 33 men $(21.6 \%)$. Millennial women are more interested in entrepreneurship in fashion and cosmetics, so that they are consistent with the type of business they are engaged in. Millennial entrepreneurs studied were aged 17-36 years; most are aged 17-21 (103 people). Research from the British Council of Indonesia (2018) shows that most leaders or founders of Indonesia are millennials. However, many businesses are still new and have been running for less than one (1) year. Most respondents in this study were 17-21 years old at the time of running a business. Many millennials have not used e-commerce facilities (applications) in this study, and only $44(28.8 \%)$ of 169 respondents used e-commerce facilities. The information technology media widely used by millennial entrepreneurs is smartphones, which amounted to $104(68.0 \%)$. It is because almost all individuals currently have smartphones to make it easier for millennial entrepreneurs to run a business. Besides, there were 32 respondents $(20.9 \%)$ who used information technology media other than smartphones and combined it with other information technology media such as smartphones, and laptops, ten respondents (6.5\%), and smartphones, laptops, computers, and tablets as many as seven respondents $(4.6 \%)$. It is in line with the national socio-economic survey (Susenas) that cellular phones show that the millennial generation is superior compared to previous generations in urban and rural areas (www.kemenpppa.go.id, 2018). 


\section{International Journal of Business Economics (IJBE)}

Vol, 2 Issue 2, pp 76-85, March - August 2021

http://jurnal.umsu.ac.id/index.php/ijbe

eISSN 2686-472X

Table 3. E-Commerce Facilities, Media Technology, Promotion Facilities, and Type of Business

\begin{tabular}{|c|c|c|c|}
\hline & Description & Amount & Percentage $(\%)$ \\
\hline \multirow[t]{3}{*}{ E-Commerce Facilities } & Not & 109 & 71.2 \\
\hline & Yes & 44 & 28.8 \\
\hline & Total & 153 & 100.0 \\
\hline \multirow[t]{5}{*}{ Media Information Technology } & Smartphone & 104 & 68.0 \\
\hline & $\begin{array}{l}\text { Smartphone \& } \\
\text { Laptop }\end{array}$ & 32 & 20.9 \\
\hline & $\begin{array}{l}\text { Smartphone, } \\
\text { Laptop \& } \\
\text { Komputer }\end{array}$ & 10 & 6.5 \\
\hline & $\begin{array}{l}\text { Smartphone, } \\
\text { Laptop, Computer } \\
\text { \& Tablet }\end{array}$ & 7 & 4.6 \\
\hline & Total & 153 & 100.0 \\
\hline \multirow[t]{5}{*}{ Electronic Promotion Facilities } & Social Media & 101 & 66.0 \\
\hline & Online Chat & 48 & 31.4 \\
\hline & Marketplace & 3 & 2.0 \\
\hline & Website & 1 & 7 \\
\hline & Total & 153 & 100.0 \\
\hline \multirow[t]{12}{*}{ Type of Business Field } & Cosmetic & 18 & 11.8 \\
\hline & Retail & 25 & 16.3 \\
\hline & Furniture & 2 & 1.3 \\
\hline & Decoration & 5 & 3.3 \\
\hline & Health & 9 & 5.9 \\
\hline & Culinary & 15 & 9.8 \\
\hline & Reseller & 4 & 2.6 \\
\hline & Education & 2 & 1.3 \\
\hline & Fashion & 56 & 36.6 \\
\hline & Services & 12 & 7.8 \\
\hline & Spareparts & 5 & 3.3 \\
\hline & Total & 153 & 100.0 \\
\hline
\end{tabular}

Based on table 3, promotions using electronic information technology media mostly use social media (Instagram, Facebook, and Line) by 101 (66.0\%). These results are consistent with research conducted by Indonesia Mom Digital Service (2017). Many millennial mothers often shop via Instagram \& Facebook, and, consistently, many millennial entrepreneurs are dominated by women in this study. While the rest use online chat (BBM and WhatsApp), only a few use the marketplace and website to promote this study. In this study, the types of business fields are divided into several types. Millennial business fields consist of fashion $(34 \%)$ then retail $(17 \%)$, cosmetics $(11.8 \%)$, culinary $(10.7 \%)$, services $(7.7 \%)$, health $(5.3 \%)$, decoration and spare parts $(6 \%)$, resellers. $(4 \%)$, education $(3 \%)$, and furniture $(2 \%)$. 


\section{International Journal of Business Economics (IJBE)}

Vol, 2 Issue 2, pp 76-85, March - August 2021

http:/ /jurnal.umsu.ac.id/index.php/ijbe

eISSN 2686-472X

Table 4. Regression Weight and Estimate Significance Value of the Relationship between Constructs

\begin{tabular}{|c|c|c|c|c|c|c|}
\hline \multicolumn{2}{|c|}{ Relationship between Constructs } & $\begin{array}{l}\text { Estimate } \\
\text { Value }\end{array}$ & $\begin{array}{l}\text { Critical } \\
\text { Ratio }\end{array}$ & $\begin{array}{l}\text { Standardized } \\
\text { Weight Value }\end{array}$ & Regression & $\begin{array}{l}\text { P- } \\
\text { Value }\end{array}$ \\
\hline $\begin{array}{l}\text { Knowledge } \\
\text { Technopreneur Millennialion } \\
\text { Techion }\end{array}$ & $\rightarrow$ & 0.340 & 2.035 & 0.334 & & 0.420 \\
\hline $\begin{array}{l}\text { Technopreneur Millennial } \\
\text { Knowledge Application } \\
\text { Technopreneur Millennial }\end{array}$ & $\rightarrow$ & 0.609 & 3.322 & 0.572 & & $* * *$ \\
\hline
\end{tabular}

Significant : $0.001(* * *)$

Source: primary data

The reference value for the critical ratio in this study is $>2.56$ at a significance level of 0.1 . If the critical ratio value is greater than $>2.56$, the causal relationship between the two constructs is significant at level 0.1. Table 4 shows the significance of the structural relationships between the constructs of the structural model. Table 4 shows that based on the CR value greater than $>2.56$ (at a significance level of 0.1 ), there is a significant relationship. Based on these assumptions, the significant value of the variable that has a CR greater than 2.56 is the causal relationship between the knowledge application construct and millennial technopreneurs with a significant level of 0.1. Meanwhile, the causal relationship between knowledge acquisition constructs and millennial technopreneur is not significant.

\section{DISCUSSION}

Based on the analysis, the results show that knowledge acquisition does not significantly affect millennial technopreneurs. This research indicates that millennial entrepreneurs who run a business by relying on technology (technopreneur) in their operations are still not maximal in several ways: 1) lack of knowledge about business partners; 2) lack of knowledge exchange between individuals; 3) less use of feedback from existing projects to improve the next project; 4) lack of knowledge about customers; 5) produce less new knowledge from existing knowledge; 6) lack of collaboration with a dedicated team to identify best practices for the business undertaken. This insignificant result is supported by convergent validity, where the average variance extracted (AVE) value is at 0.50 in table 1 and is the lowest value compared to other constructs. Thus this study does not support the hypotheses and theories and research of Smith (2003), Hwa (2009), Bon (2010), and Pratomo (2010). Besides, this study provides results that the application of knowledge has a significant effect on millennial technopreneurs. Meanwhile, this study supports the hypothesis, theory, and research of Mehdi and Shaemi (2010), Madhousi et al. (2011), Mohannak, and Matthews (2011). Millennial entrepreneurs who are included in this research have a process to apply knowledge learned from experience, have a process to use knowledge in developing new products or services, and use knowledge to solve new problems. The millennial entrepreneurs also adjust their sources of knowledge to problems and challenges faced, using knowledge to improve business efficiency, using knowledge to adjust strategic business direction. Discover and apply knowledge to changing competitive conditions, making knowledge accessible to those in need, and quickly applying knowledge to pressing competitive needs.

\section{Implications}




\section{International Journal of Business Economics (IJBE)}

Vol, 2 Issue 2, pp 76-85, March - August 2021

http:/ /jurnal.umsu.ac.id/index.php/ijbe

eISSN 2686-472X

Millennials are the successors of future generations. Millennial entrepreneurs play an important role in using, utilizing, and relying on technology in business processes. Knowledge is an important asset in realizing competitiveness in achieving a competitive advantage for millennial entrepreneur businesses. Besides, knowledge acquisition is the first and very important process in the knowledge management process. It is because acquiring knowledge from external parties/sources will provide insights for an individual's stock knowledge to increase before carrying out the knowledge process to apply knowledge. In digital technology, business processes are highly dependent on the sophistication of technology and information systems used so that millennial knowledge goes through cognitive and affective processes before applying knowledge. Millennial entrepreneurs need to adopt knowledge (acquisition) regarding the suitability of technology and the business being carried out so that the knowledge acquisition process of technology utilization in millennial entrepreneurship will survive and develop from time to time.

\section{CONCLUSION}

Process in knowledge management requires individuals to acquire knowledge first before applying it. So that knowledge can be used properly and by its benefits and filtered properly, knowledge acquisition is the first process that needs to be carried out by individuals who are millennial entrepreneurs who use technology in carrying out their business activities. This study found that millennial entrepreneurs have neglected the process of acquiring knowledge of the business needed. The millennial entrepreneurs studied did not pay attention to knowledge acquisition but instead directly applied the knowledge and applied the knowledge as it was. The millennial entrepreneurs have used smartphones, laptops, computers, and tablets to support their businesses but are still weak in using e-commerce facilities extensively in their business processes. It can be seen in respondents' descriptive data, which shows that of the 153 respondents studied, only 44 people used e-commerce to support business activities. Technology, such as e-commerce, plays an important role in the current era and supports business processes.Because this research was conducted online, so there was no direct contact with the respondents. The next research is suggested to map similar businesses in the same group or business so that the treatment of the theory used can be maximized in its measurement. This effort can increase the generalizability of research results so that the ability to predict is strong between theory and facts in the field.

\section{REFERENCES}

Bon, Abdul Talib (2010). New Model and Concept For Technoprenuership Studies In University Through Exellence Center. Kebangsaan, $P ., \&$ Kejuruteraan, P. Continuing Education, (September), 63-67. https://doi.org/10.1002/ajpa.

British Council Indonesia (2018). Available at: https://static.usahasosial.com/wpcontent/uploads/2018/12/developing_inclusive_creativ e_economy_the_state_of_social_enterprise_in_indoensia_british_council_un_escap_pl us_platform_usaha_sosial.pdf. Accessed and Downloaded on 12 October 2019.

Cooper, D. R. and Schindler, P. S. (2011), 'Business Research Methods'. 9th Edition McGraw-Hill.

Dailysocial.id., (2016). Available at: https://dailysocial.id/report/post/indonesias-tech-startupreport-2016\#. - Accessed and Downloaded on 12 March 2018. 


\section{International Journal of Business Economics (IJBE)}

Vol, 2 Issue 2, pp 76-85, March - August 2021

http://jurnal.umsu.ac.id/index.php/ijbe

eISSN 2686-472X

Darr, E. D., Argote, L., \& Epple, D. (1995). The Acquisition, Transfer, and Depreciation of Knowledge in Service Organizations: Productivity in Franchises. Management Science. https://doi.org/10.1287/mnsc.41.11.1750.

Gold, H., Andrew, Malhotra, Arvind and Segars H., Albert. (2001). Knowledge Management : An Organizational Capabilities Perspectives. Journal of Management Information Systems. Summer 2001; 18,1, pg. 185.

Hair, J. F; Anderson, R. E; Tatham R. T. and Black W. C. (2010). 'Multivariate Data Analysis, 7th Edition'. Prentice Hall, Upper Saddle River, NJ.

Howe, N., Strauss, W., \& Strauss, N. H. \& W. (2007). Millennials go to college. Millennials Go to College, 1-4. Retrieved from http://eubie.com/millennials.pdf.

Hwa, Chua Eng. (2009). An Action Learning Journey of a Technopreneur in Creating, Sustaining and Growing a World Class Knowledge-Based Teaching Organisation in Factory Automation in the 21st Century. Available at : http://www.fasystems.com.sg/Chua\%20Eng\%20Hwa,\%20An\%20Action\%20Learning \%20Journey\%20of\%20a\%20Technopreneur.pdf.

Indonesian Digital Mums Survey. (2017). https://issuu.com/theasianparent/docs/tap_survey_report-110917. - Accessed and Downloaded on 27 March 2019).

Idntimes.com., (2017).

Available

at: https://www.idntimes.com/business/economy/imansuryanto/millennials-disarankanuntuk-berwirausaha/full (25 Oktober 2017). - Accessed on 15 Desember 2019.

Jakarta Post. (2017). Available at: http://www.thejakartapost.com/longform/2017/03/03/the2017-indonesian-startup-popular-sector-forecast.html. - Accessed on 21 April 2018.

Kemenpppa.go.id., (2018).

Available

at: https://www.kemenpppa.go.id/lib/uploads/list/9acde-buku-profil-generasi-milenia.pdf. Accessed on 15 Desember 2018.

Livescience.com., (2017). Available at: https://www.livescience.com/38061-millennialsgeneration-y.html (September 8, 2017). Accessed and Downloaded on 10 October 2019.

Madhoushi, M., Sadati, A., Delavari, H., Mehdivand, M. and Mihandost, R. (2011). "Entrepreneurial Orientation and Innovation Performance: The Mediating Role Of Knowledge Management”. Asian Journal of Business Management, Vol. 3, No. 4, pp. 310-316.

Manpower Group. (2016). Millennial Careers : 2020 Vision. Manpower Group. Available at: https://www.manpowergroup.com/millennials : Accessed and Downloaded on 12 October 2019.

Mehdi, Abzari, and Ali, A., Shaemi, (2010). Study of Amount of Paying Attention to Knowledge Management and providing Solutions (Case study: Automobile Industry of Iran). European Journal of Social Sciences - Volume 15, Number 4 (2010).

Mohannak, Kavoos \& Matthews, Judy H. (2011). Managing Specialised Knowledge in Technopreneurial Firms : The Australian Experience.(Eds.) XXII ISPIM Conference : Organizational Future Orientation, 12 - 15 June, 2011, Hamburg, Germany. Available at: https://eprints.qut.edu.au/42497/.

Ngah, Rohana and Ibrahim, Abdul Razak, (2009). The Relationship of Intellectual Capital, Innovation dan Organizational Performance: A Preliminary Study in Malaysian SMEs. International Journal of Management Innovation Systems, Vol. 1 No. 1:E1, pp. 1-13. 


\section{International Journal of Business Economics (IJBE)}

Vol, 2 Issue 2, pp 76-85, March - August 2021

http://jurnal.umsu.ac.id/index.php/ijbe

eISSN 2686-472X

Nonaka, I. dan Takeuchi, H. (1995). The Knowledge-Creating Company: How Japanese Companies Create the Dynamics of Innovation. New York,NY : Oxford University Press.

Pratomo, Yudha (2010). Utilization of Human Virtual Intelligence Framework in Managing Technopreneur Knowledge. Jurnal Generic. Vol. 5 No.1 (Januari 2010). Available at: http://journal.portalgaruda.org/index.php/generic/article/view/113.

Smith, John Milton (2003). Developing Technopreneurs In Asia: A Strategic Management Research Perspective. School of Management Working Paper, Number 2003:1, February 2003. Available at: https://espace.curtin.edu.au/bitstream/handle/20.500.11937/18668/19685_downloaded_ stream_203.pdf?sequence $=2 \&$ is Allowed $=y$.

The Economist Intelligence Unit. Industries in $2018:$ A special report (www.eiu.com/industry).

W\&S Market Research. (2014). Available at: http://nusaresearch.com/upload/userfiles/files/TOPLINE\%20FINDING_ECOMMERC E_ENG.pdf. (W\&S Research). - Accessed and Downloaded on 21 September 2019. 